\title{
PENGARUH KARAKTIERISTIK TOKO TERHADAP PENGALAMAN KONSUMEN GERAI KOPI
}

\section{THE EFECTOF STORE C HARAC TERISTIC S ON COFEE SHOP'S C USTOMER EXPERIENCE}

\author{
Sri Nathasya Br Sitepu ${ }^{1 *}$, Angelica Irene Christina ${ }^{1}$ \\ 1Program Studi Manajemen, Fakultas Ma najemen dan Bisnis, Universitas Ciputra \\ Add ress: ${ }^{1}$ Citra Land CBD Boulevard, Made, Surabaya, 60219, J a wa Timur, Indonesia \\ *E-mail : na thasya.sitepu@ciputra.ac.id
}

\begin{abstract}
ABSTRAK
Penelitian ini berupaya mengana lisis dampak karakteristik gerai kopi terhadap pengalaman yang diperoleh konsumen saat berada di gerai. Karakteristik gerai kopi yang diamati dalam penelitian ini meliputi karakteristik fungsional, suasana, desain, dan sosial. Penelitian ini memiliki populasi seluruh penduduk Surabaya berusia produktif, dan sampel penelitian ditentukan menggunakan rumus Isaac dan Michael dan Sampling Kuota dengan ciri-cin responden pemah mengunjungi dan/atau mengonsumsi produk langsung di gerai kopi Starbuc ks Sura baya maksimal 2-3 bulan sebelum pengisian kuesioner, hingga diperoleh total responden penelitian 384 orang. Kuesioner penelitian ini dibagikan secara online dan offline, dengan total kuesioner yang dipakai sejumlah 369 kuesioner. Penelitian ini menggunakan analisis SEM. Penelitian ini menemukan bahwa hanya ka rakteristik fungsional dan sosial kedai kopi yang berpengaruh signifikan terhadap aspek pengalaman yang diperoleh konsumennya; sedangkan karakteristik suasana dan desain tidak berpengaruh signifikan, bahkan karakteristik desa in berpengaruh negatif terhadap aspek pengalaman konsumen. Kontribusi praktis penelitian bagi gerai kopi a dalah untuk memperta hanka n a spek fungsional dan sosial serta, memperbaiki aspek karakteristik desain dan suasana agar konsumen mendapatkan pengalaman ketika berkunjung.
\end{abstract}

Kata Kunci: experience marketing, karakteristik gerai, pengalaman konsumsi, Structural Equation Modeling (SEM)

Klasifikasi JEL : M31, L83

\begin{abstract}
This research attempts to examine the impact of the coffee shop characteristic s towards the consumers experience when they visit the coffee shop. The coffee shop characteristics including functional, atmosphere, design, and social characteristics. The population of this study are all Surabaya productive age residents, and the sample of this study was determined using Quota Sampling and the Isaac and Michael formula with the respondents requirements are those who had been visiting and/or consuming products directly at Starbucks Surabaya on maximum of $2-3$ months before filling out the questionnaire, with total of 384 respondents needed to be obtained. The questionnaire was distributed online and offline, with total 369 questionnaires a re used in this study. This research uses SEM a nalysis. This research found that only the functional and social characteristics of the coffee shop have signific ant effect on the experience gained by its consumers; while the atmosphere and design characteristics have no signific ant effect, as the design characteristic s have negative effect on the consumers experience. The practical contribution of research for the coffee shop owner a re to ma intains functional and social aspects as well as, improving aspects of design characteristic s and atmosphere so that consumers ga in experience when visiting.
\end{abstract}

Keywords: experience marketing, outlets characteristics, consumers experience, Structural Equation Modeling (SEM)

JElClassification : M31, L83

Article History:

Received: May 3, 2020; Revised: August 13, 2020; Accepted: August 13, 2020; Available Online: August 28, 2020

DOI: $10.20473 /$ jmtt.v13i2.18930

(C2020 Sri Nathasya Br Sitepu, Angelica Irene Christina. Published in Jumal Manajemen Teori dan Terapan. Published by Universitas Airlangga, Department of Management. This a rticle is published under the Creative Commons Attribution (CC BY 4.0) lic ence. 138 


\section{PENDAHULUAN}

Zaman berkembang semakin modem, temasuk di bidang ekonomi. Perkembangan teknologi juga dirasakan oleh sektor bisnis temasuk ketika melaksanakan proses transaksi perdagangan (pra traksaksi, transaksi dan pasca transaksi). Penerapan teknologi pada bisnis menambah pengalamaan baru bagi konsumen (Hoyer et al., 2020). Selain inovasi pada penerapan teknologi perusahaan juga berinovasi aspek penawaran. Jika dulu perusahaan hanya dapat menawarkan produk mentah, produk jadi, a taupun jasa; kini perusahaan juga dapat menawarkan suatu bentuk pengalaman tak terlupakan yang mampu meninggalkan kesan tersendir bagi konsumen secara pribadi (Triantafillidou et al., 2017). Prilaku konsumen dipengaruhi oleh faktor kebutuhan akan barang/jasa serta keinginan menghabiskan waktu luang (Lucia-Palacios, Pérez-López dan Polo-Redondo, 2016). Roggeveen, Grewal dan Schweiger (2020)dalam penelitiannya bahkan menemukan bahwa kerangka desaina mbient-sosial-trialability (DAST) yang ditawarkan oleh retail berhasil mempenga ruhi prilaku konsumen dalam berbelanja. Hal ini mendasari konsumen untuk mencari experiential marketing sebagai suatu bentuk penawaran ekonomi yang unik, karena mampu menawarkan berbagai kesan mendalam bagi konsumen, serta mampu menarik konsumen untuk ikut berpartisipa si aktif ma upun pasif (Merdin-Uygur, 2018). Konsumen da pat menikmati pengalaman dan kegiatan sosialisasi dengan orang baru, menghabiskan waktu dan memperdalam ikatan dengan orang terdekat, atau bahkan menjadi anggota suatu tim (Triantafillidou dan Siomkos, 2014). Konsumen membeli produk (barang/jasa) berdasarkan pengalaman saat mengkonsumsi. Konsumsi berdasarkan pengalaman aspek experiental marketing ketika konsumen berbelanja kopi menarik diteliti ka rena bisnis gerai kopi semakin banyak bermunculan dimana setiap gerai kopi menawarkan experiental marketing yang berbeda-beda kepada setiap konsumen yang berkunjung ke geraikopi.

Experiential marketing sendiri kini makin menjamur di Indonesia. Perkembangan industri kopi mengalami kompetisi tersendiri di antara pendiri-pendin kedai kopi luar negeri yang membuka cabang di Indonesia maupun gerai kopi lokal yang menawarkan pengalaman unik dan relaxing bagi para konsumen kopi. Konsumen mendapat pengalaman ketika berada digerai kopi maupun saat mengkonsumsi produk/jasa yang disediakan di gerai kopi. Pengalaman unik dan relaxing yang ditawarkan gerai kopi bertujuan agar konsumen betah berlama-lama menghabiskan waktu di kedai kopinya. Gerai kopi saat ini tidak hanya sekedar melayani dan menyediakan berbagai macam produk kopi berkualitas dunia bagi konsumennya mela inkan, menciptakan pengalaman dan membangun kenyamanan untuk berinteraksi antar individu (konsumen). Melkisedek (2017) menjelaskan fungsi gerai kopi melalui ketersediaan karakteristik fungsional, suasana, desa in dan ka rakteristik sosial. Gerai kopi harus mampu membangun kesadaran mereknya dengan baik dan kuat di kalangan konsumen setianya (Wicaksono dan Prihastuti, 2017). Antusiasme masyarakat Indonesia 


\section{Sri Nathasya BR Sitepu \\ Angelica Irene Christina}

terhadap gerai kopi sendir cukup tinggi, dilihat dengan semakin menjamumya gerai kopi tidak terkecua li di Surabaya.

Penelitian ini akan menganalisis dampak karakteristik gerai kedai terhadap pengalaman yang diperoleh konsumen saat berkunjung dan/atau melakukan konsumsi secara langsung di gerai. Tujuan penelitian ini mengusulkan strategi pemasaran yang efektif bagi manajemen pemasaran bisnis (khususnya kedai kopi), berdasarkan implementasi strategi experiential marketing di gerai kopi Surabaya. Penelitian ini dilakukan terhadap konsumen usia produktif (15-64 tahun), yang melakukan kunjungan dan/atau konsumsi secara langsung di gerai kedai kopi Surabaya pada bulan Oktober 2019 hingga Januari 2020. Kontribusi praktis penelitian bagi gerai kopi mempertahankan aspek fungsional dan sosial serta, memperba iki aspek karakteristik desain dan suasana agar konsumen mendapatkan pengalaman ketika berkunjung. Implikasi penelitian bagi manajemen pemasaran menjadi tambahan literatur yang menjelaskan pentingnya karakteristik fungsional dan sosial terhadap pengalaman konsumen di gerai kopi. Pengalaman konsumen merupakan aspek penting dalam ilmu manajemen pemasaran.

\section{TINJ AUAN PUSTAKA}

\section{Pengalaman yang Diperoleh Konsumen (Experiential Marketing)}

Pada awalnya, experiential marketing bertujuan memberikan Fantasies, Feelings, dan Fun (3F) terhadap konsumennya; di mana pendekatan ini bertujuan untuk mengubah konsumen yang awalnya datang atas tujuan tertentu dan bersikap rasional, menjadi lebih emosional dan bahagia setelah melakukan proses konsumsi (Datta, 2017). Seining berkembangnya waktu, experiential marketing kemudian berkembang menjadi strategi modem marketing yang mulai mengambil alih peran strategi traditional marketing, terlebih karena modem marketing mampu membawakan dan memperhitungkan aspek emosional dan pengalaman yang dirasakan konsumen (Datta, 2017). Pengalaman konsumen memiliki pengaruh yang sama satu sama lain pada respons pasca-konsumsi yang diperoleh saat mengunjungi toko. Atribut toko berupa: suasana, layanan dan desain secara signifikan berpengaruh terhadap kepuasan konsumen ketika berbelanja (J ohnson et al., 2015). Faktor pendorong la in pada perasaan nostalgia konsumen, komunikasi dan keinginan berperilaku WOM dipengaruhi oleh perasa an escapism, pembelajaran, dan komunitas; sebaliknya, flow dan tantangan tidak berpengaruh sama sekali pada respons pasca-konsumsi konsumen. Triantafillidou et al. (2017) sendin menemukan bahwa pengalaman berbelanja di retail fashion dapat dibagi menjadi hedonism, flow, escapism, tantangan, pembelajaran, sosialisasi, dan komunitas; dimana setiap variabel tersebut dipengaruhi oleh berbagai ka ra kteristik atmosfer toko tersebut: functional characteristics (ketersediaan produk, kualitas produk, harga produk, dan product range), ambient characteristics (musik, aroma, dan 
pencahayaan), design characteristics (layout dan dekorasi), dan social characteristics (kesopanan karyawan). Pengaruh yang signifikan antara variabel experiental marketing (sense , feel, think, act, dan relate) terhadap kepuasan pelanggan, di mana variabel relate berpengaruh dominan terhadap kepuasan pelanggan (Wicaksono dan Prihastuti, 2017). Experiental marketing juga diteliti pada anak muda dan menemukan bahwa intensi untuk konsumsi secara insidentil di kalangan anak muda dipengaruhi variabel pengalaman (Dey dan Srivastava, 2017).

\section{Karakteristik Fungsional}

Karakteristik fungsional menupakan komponen penting untuk mendorong konsumen dalam memilih produk/jasa. Konsumen dapat merasakan karakteristik fungsional mela lui kombinasi antara pengalaman konsumsi dan ketersediaan atribut toko yang disediakan pemilik toko (Sachdeva dan Goel, 2015). Karakteristik fungsional suatu toko dapat diukur dengan 4 ind ika tor, ya itu varian, harga, kua litas, da n ketersedia an produk (Tria nta fillidou et al., 2017).

\section{Karakteristik Suasana}

Karakteristik suasana toko atau ambience menupakan salah satu sarana komunikasi yang memiliki dampak positif dan dibuat menarik. Karakteristik sua sana mampu mempengaruhi emosi dari konsumen (Sukma, DH dan Yaningwati, 2012). Penelitian ini meneliti karakteristik suasana kedai kopi dari segi music, background, aroma, dan pencahayaan (Triantafillidou et al., 2017). Kualitas produk dan musik back ground di dalam toko menjadi karakteristik paling penting dalam mempengaruhi mayoritas variabel pengalaman in-store leisure shopping, diikuti dengan karakteristik layout toko dan aroma (Triantafillidou, Siomkos dan Papafilippaki, 2017). Penelitian ini juga menemukan pengaruh negatif varian produk terhadap variabel pengalaman in-store leisure shopping (Triantafillidou, Siomkos dan Papafilippaki, 2017). Hasil penelitian lainnya menunjukkan bahwa atmosfer toko dapat menimbulkan perasaan positif pada konsumen saat berada di lokasi, kepuasan konsumen, dan konsumen memiliki intensi untuk kembali lagi baik secara langsung maupun tidak langsung (melalui kepuasan konsumen). Perasaan positif konsumen juga mempengaruhi kepuasan konsumen serta perilaku dan intensinya untuk kembali lagi (Sitinjak, Pangaribuan dan Tafriza, 2019). Hasil penelitian lain menunjukkan bahwa pengalaman core-consumption menyebabkan keinginan nostalgia yang kuat terhadap para peserta, sehingga kemudian mereka melakukan aktivitas word-of-mouth dengan memuji aktivitas ini, serta kembali melakukan aktivitas ini (Tria nta fillid ou \& Siomkos, 2013). 


\section{Karakteristik Desain}

Ka rakteristik desa in toko menujuk pada persepsi konsumen terhadap layout toko secara fisik, rak display toko (Triantafillidou, Siomkos dan Papafilippaki, 2017). Penelitian ini meneliti ka rakteristik desa in Starbuc ks Sura baya berda sarkan 2 indikator utama: la yout dan dekorasi; di mana layout sendir meliputi layout toko dan rak display di dalam toko ( Triantafillidou et al., 2017). Atribut atau display kafe berpengaruh signifikan terhadap motif belanja hedonis dan motif belanja utilitarian; namun tidak ada pengaruh signifikan terhadap loyalitas pelanggan gerai kopi. Namun baik motif belanja hedonis maupun motif belanja utilitarian memiliki pengaruh signifikan terhadap loyalitas pelanggan gerai kopi (Leha dan Subagio, 2014).

\section{Karakteristik Sosial}

Ka rakteristik sosial mengarah kepada sekelompok individu yang berinteraksi agar mencapai tujuan individu maupun tujuan secara bersama (Marlius, 2017). Karakteristik sosial juga merupakan sikap (kesediaan) individu yang peduli dan perhatian secara mendalam dan khusus kepada setiap pelanggan (Widjoyo, 2013). Penelitian tergadulu menunjukkan bahwa pengalaman core-consumption menyebabkan keinginan nostalgia yang kuat terhadap para peserta, sehingga kemudian mereka melakukan aktivitas word-of-mouth dengan memuji a ktivitas ini, serta kembali mela kukan a ktivitas ini (Tria nta fillid ou \& Siomkos, 2013).

\section{Hubungan Antar Variabel dan Hipotesis}

Karakteristik fungsional berpengaruh positif dan signifikan terhadap pengalaman yang diperoleh konsumen saat melakukan konsumsi. Image gerai Starbucks Surabaya sebagai obyek dalam penelitian ini dipenganuhi karakteristiknya yang secara fisik dan simbolis menunjukkan produk yang dijualnya, di mana konsumen akan lebih mudah mencapai tujuannya dengan karakteristik fungsional gerai yang jelas (Triantafillidou, Siomkos dan Pa pa filippaki, 2017). Maka dari itu diperoleh hipotesis:

\section{$\mathrm{H}_{\text {: }}$ Karaktenistik fungsional gerai Starbucks di Surabaya berpenganuh signifikan terhadap aspek pengalaman yang diperoleh konsumen Starbucks.}

Ka ra kteristik suasana berhubungan positif dan signifikan terhadap pengalaman konsumen di gera i Starbucks Surabaya. Sua sana gera i Starbucks Sura baya seperti musik background dan aroma kopinya mampu memancing emosi dan memori positif bagi konsumen, bahkan pencahayaan yang tepat akan mampu menarik konsumen untuk berlama-lama di da la mnya (Tria nta fillidou, Siomkos dan Pa pa filip paki, 2017). Maka dari itu diperoleh hipotesis:

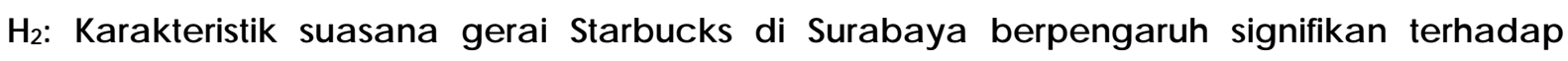
aspek pengalaman yang diperoleh konsumen Starbucks. 
Karakteristik desain berhubungan positif dan signifikan terhadap apa yang dirasakan konsumen saat berada di gerai Starbucks Surabaya. Desa in mampu mempengaruhi konsumen, misalnya nuansa layout gerai yang bagus dan rapi mampu member perasaan senang dan bahagia bagi konsumen (Triantafillidou, Siomkos dan Papafilippaki, 2017). Maka dari itu diperoleh hipotesis:

$H_{3}:$ Karaktenistik desain gerai Starbucks di Surabaya bemenganuh signifikan terhadap aspek pengalaman yang diperoleh konsumen Starbucks.

Ka rakteristik sosial berhubungan positif dan signifikan terhadap pengalaman yang diperoleh konsumen di gerai Starbucks Surabaya; di mana penelitian sebelumnya menjelaskan bahwa semakin sopan dan ramah karyawan, serta semakin baik penampilan karyawan toko dan konsumen lainnya, semakin tinggi pula perasaan positif dan kepuasan konsumen (Tria nta fillid ou, Siomkos dan Pa pafilip paki, 2017). Maka dari itu diperoleh hipotesis:

H4: Karakteristik sosial gerai Starbuck di Surabaya berpenganuh signifikan terhadap aspek pengalaamaan yang diperoleh konsumen Starbuck.

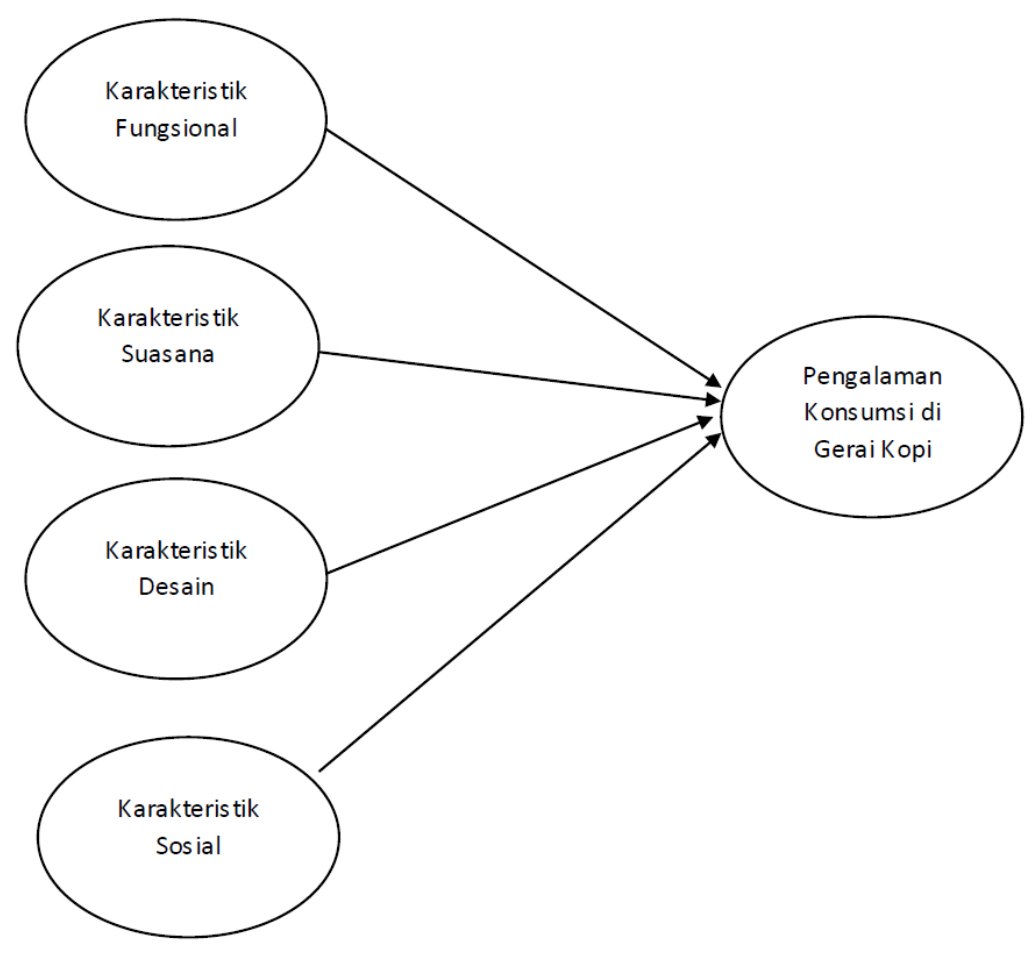

Gambar 1.

Model Penelitian 


\section{Sri Nathasya BR Sitepu \\ Angelica Irene Christina}

\section{METODE ANAUSIS}

Penelitian ini menggunakan metode penelitian deskriptif dengan data kuantitatif, menggunakan penelitian korelasi yang dirancang untuk menentukan hubungan antar variabel yang berbeda (Sunyoto, 2013). Populasi penelitian ini adalah seluruh penduduk Surabaya, terhitung sebesar 2.765.487 jiwa berdasarkan data Sensus Penduduk terakhir di tahun 2010 (Badan Pusat Statistik Kota Surabaya, 2018). Peneliti kemudian menyesuaikan populasi penelitian berdasarkan segmentasi konsumen Starbucks di Surabaya yaitu orang kantoran dan mahasiswa, yang terbiasa menghabiskan waktu di gerai kopi (Numanisa, Wilopo dan Sanawiri, 2016). Peneliti melakukan penyempitan populasi pada usia produktif dalam istilah Angka Beban Tanggungan menurut Badan Pusat Statistik (2020), yaitu penduduk berusia antara 15 sampai 64 tahun. Maka dari itu populasi penelitian yang telah disesuaikan kembali, dengan asumsi penduduk di kelompok 'Tak Terjawab' diabaikan, sehingga diperoleh total populasi berjumlah 1.999 .142 jiwa (982.460 jiwa laki-laki dan 1.016.742 jiwa perempuan).

\section{Tabel 1 .}

Variabel Penelitian dan Item Pengukuran

\begin{tabular}{|c|c|}
\hline Variabel & Indikator \\
\hline \multirow{4}{*}{ Ka ra kteristik Fungsional $\left(\mathrm{X}_{1}\right)$} & 1.1. Ketersediaan Produk ( $\left.\mathbf{X}_{\mathbf{1 . 1}}\right)$ \\
\hline & 1.2. Varian Produk $\left(\mathbf{X}_{\mathbf{1 . 2}}\right)$ \\
\hline & 1.3. Harga Produk ( $\left.\mathbf{X}_{\mathbf{1 . 3}}\right)$ \\
\hline & 1.4. Kualitas Produk $\left(\mathbf{X}_{\mathbf{1} . \mathbf{4}}\right)$ \\
\hline \multirow{3}{*}{ Ka ra kteristik Sua sana $\left(\mathrm{X}_{2}\right)$} & 2.1. Musik background $\left(\mathbf{X}_{2.1}\right)$ \\
\hline & 2.2. Aroma $\left(\mathbf{X}_{2.2}\right)$ \\
\hline & 2.3. Pencahayaan $\left(\mathbf{X}_{\mathbf{2 . 3}}\right)$ \\
\hline \multirow{2}{*}{ Ka ra kteristik Desa in $\left(\mathrm{X}_{3}\right)$} & 3.1. Layout $\left(\mathbf{X}_{\mathbf{3 . 1}}\right)$ \\
\hline & 3.2. Dekorasi $\left(\mathbf{X}_{\mathbf{3 . 2}}\right)$ \\
\hline Ka ra kteristik Sosial $\left(\mathrm{X}_{4}\right)$ & 4.1. Kesopanan Karyawan ( $\left.\mathbf{X}_{\mathbf{4 . 1}}\right)$ \\
\hline \multirow{8}{*}{$\begin{array}{l}\text { Pengala man Konsumsi di } \\
\text { Gerai Sta rbucks Surabaya (Y) }\end{array}$} & 1. Hedonisme $\left(\mathbf{Y}_{\mathbf{1}}\right)$ \\
\hline & 2. Flow $\left(\mathbf{Y}_{\mathbf{2}}\right)$ \\
\hline & 3. Escapism $\left(\mathbf{Y}_{\mathbf{3}}\right)$ \\
\hline & 4. Pembelajaran $\left(\mathbf{Y}_{\mathbf{4}}\right)$ \\
\hline & 5. Sosia lisa si ( $\left.\mathbf{Y}_{\mathbf{5}}\right)$ \\
\hline & 6. Komunitas $\left(\mathbf{Y}_{6}\right)$ \\
\hline & 7. Kebaruan/novelty ( $\left.\mathbf{Y}_{\mathbf{7}}\right)$ \\
\hline & 8. Pujian dari yang Lain $\left(\mathbf{Y}_{\mathbf{8}}\right)$ \\
\hline
\end{tabular}

Sampel penelitian ini ditentukan jumlahnya menggunakan rumus Isaac dan Michael, dengan hasil penghitungan penentuan jumlah sampel berdasarkan tingkat kesalahan $1 \%$, $5 \%$, dan $10 \%$. Berdasarkan rumus tersebut, diperoleh jumlah sampel penelitian ini sebesar 384,026 jiwa yang dibulatkan menjadi 384 jiwa, dengan tingkat kesalahan 5\%. Selanjutnya penelitian ini menggunakan non-probability sampling design, berupa purposive sampling. Kriteria sampling diantaranya: responden harus sudah mengunjungi dan/atau mengonsumsi produk langsung di gerai Starbuc ks di Sura baya maksimal 2-3 bulan sebelum penelitian. 


\section{Metode Pengumpulan Data}

Metode pengumpulan data adalah bagian instrumen pengumpulan data yang menentukan berhasil tidaknya suatu penelitian (Bungin, 2015). Penelitian ini menggunakan metode survei dengan penyebaran kuesioner yang diadopsi dari penelitian oleh Triantafillid ou et al. (2017) dan Dey dan Srivastava (2017). Kuesioner dibagikan ke responden yang berdomisili di sekitar gerai dan secara langsung berlanja di gerai Starbucks Surabaya pada November 2019 hingga J anuari 2020.

\section{Metode Analisis dan Pengujian Hipotesis}

Penelitian ini menggunakan analisis SEM (Structural Equation Modeling) dalam pengujian hipotesisnya, dengan model umumnya terdin atas dua bagian (Haryono, 2017:2-3)yaitu model pengukuran dan model structural. Model pengukuran/measurement model, yang menghubungkan variabel laten (unobserved variable) dengan indikatomya (observed variable) sehingga pengujian signifikansi model ini dapat dilakukan dengan uji Confimatory Factor Analysis (CFA). Model struktural/structural model menghubungkan antar variabel laten baik endogen maupun eksogen melalui persamaan regresi simultan, di mana pengujian signifikansi model ini dapat dilakukan menggunakan kriteria Goodness-of-Fit (GOF)).

Penelitian ini mengguna kan model SEM jenis ha rd-modeling a ta u CB-SEM (Covariance Ba sed - Structural Equation Modeling), yang bertujuan untuk menguji hubungan kausalitas antar variabel yang dibangun berdasarkan teori; apakah model penelitian mampu dikonfimasi dengan data empirisnya (Haryono, 2017). Ghozali, (2017)dengan pengembangan dari Haryono (2017) menya takan ta hap permodelan dan a na lisis persa maan struktural a da lah (1) pengembangan model berdasarkan teor, (2) menyusun diagram jalur dan persamaan struktural, (3) memilih jenis input matriks dan estimasi model yang diusulkan, (4) uji kelayakan model, (5) analisis koefisien deteminasi, dan (6) interpretasi dan respesifikasi model. Uji kelayakan model dilakukan melalui pengujian nomalitas distribusi data dan offending estima te, pengujian signifikansi model pengukuran dengan CFA,menilai kriteria Goodness-ofFit,uji signifikansi model pengukuran dengan tahapan convergent validity, variance extracted, construct reliability, disc rimina nt va lid ity, 
HASILDAN PEMBAHASAN

Analisis Deskriptif Variabel Penelitian

Data deskriptif untuk variabel independent yaitu: karakteristik fungsional (X1), ka rakteristik suasana (X2), ka rakteristik disgn (X3), dan ka rakteristik sosial (X4). Nilai standar deviasi setiap indikator dari variabel independent lebih dari 0,6 yang memiliki makna indikator sudah homongen. Nilai mean dari masing-masing indikator yang ada pada variabel independent diatas 3 yang menunjukkan respon dari responden masih berada dalam kategorisasi Setuju.

Tabel 2.

Statistik Deskriptif dari Va ria bel Independen Penelitian

\begin{tabular}{|c|c|c|c|}
\hline Indikator Variabel X & Sub Indikator & Mean & Standar Deviasi \\
\hline \multirow{2}{*}{$\begin{array}{l}\text { Ketersediaan Produk } \\
\text { (X1.1) }\end{array}$} & $\mathrm{X} 1.1 .1$ & 3,98 & 0,71 \\
\hline & $\mathrm{X} 1.1 .2$ & 3,87 & 0,76 \\
\hline \multirow{2}{*}{ Varian Produk (X1.2) } & $\mathrm{X} 1.2 .1$ & 3,95 & 0,76 \\
\hline & $\mathrm{X} 1.2 .2$ & 3,98 & 0,70 \\
\hline \multirow{2}{*}{ Harga Produk (X1.3) } & $\mathrm{X} 1.3 .1$ & 3,72 & 0,80 \\
\hline & $\mathrm{X} 1.3 .2$ & 3,73 & 0,80 \\
\hline \multirow{2}{*}{ Kua litas Prod uk (X1.4) } & X1.4.1 & 3,82 & 0,70 \\
\hline & $\mathrm{X} 1.4 .2$ & 3,85 & 0,63 \\
\hline Musik ba c kground (X2.1) & $X 2.1$ & 3,86 & 0,70 \\
\hline Aroma $(X 2.2)$ & $\mathrm{X} 2.2$ & 3,82 & 0,76 \\
\hline Pencahayaan (X2.3) & $\mathrm{X} 2.3$ & 3,93 & 0,70 \\
\hline La yout (X3.1) & X3.1 & 3,85 & 0,67 \\
\hline \multirow[b]{2}{*}{ Dekorasi (X3.2) } & X3.2.1 & 3,89 & 0,69 \\
\hline & $\mathrm{X} 3.2 .2$ & 3,92 & 0,73 \\
\hline \multirow{2}{*}{$\begin{array}{l}\text { Kesopanan Karyawan } \\
\text { (X4.1) }\end{array}$} & X4.1.1 & 3,96 & 0,73 \\
\hline & $\mathrm{X} 4.1 .2$ & 3,83 & 0,75 \\
\hline \multirow{2}{*}{ Indikator Vaniabel Y } & Sub Indikator & Mean & StandarDeviasi \\
\hline & $\mathrm{Y} 1.1$ & 3,96 & 0,74 \\
\hline \multirow{3}{*}{ Hedonisme (Y1) } & Y1.2 & 3,81 & 0,83 \\
\hline & Y1.3 & 3,85 & 0,74 \\
\hline & Y1.4 & 3,77 & 0,77 \\
\hline \multirow{3}{*}{ Flow (Y2) } & Y2.1 & 3,88 & 0,70 \\
\hline & Y2.2 & 3,83 & 0,74 \\
\hline & Y2.3 & 3,78 & 0,78 \\
\hline \multirow{2}{*}{ Esc ap ism (Y3) } & Y3.1 & 3,64 & 0,87 \\
\hline & Y3.2 & 3,64 & 0,90 \\
\hline \multirow{2}{*}{ Pembelajaran (Y4) } & Y4.1 & 3,74 & 0,81 \\
\hline & Y4.2 & 3,78 & 0,83 \\
\hline \multirow{3}{*}{ So sia lisa si (Y5) } & Y5.1 & 3,59 & 0,91 \\
\hline & Y5.2 & 3,59 & 0,93 \\
\hline & Y5.3 & 3,82 & 0,78 \\
\hline \multirow{2}{*}{ Komunitas (Y6) } & Y6.1 & 3,78 & 0,82 \\
\hline & Y6.2 & 3,8 & 0,78 \\
\hline \multirow{2}{*}{ Kebaruan/novelty (Y7) } & Y7.1 & 3,77 & 0,79 \\
\hline & Y7.1 & 3,77 & 0,8 \\
\hline \multirow{2}{*}{ Pujian dari yang Lain (Y8) } & Y8.1 & 3,73 & 0,88 \\
\hline & Y8.2 & 3,75 & 0,88 \\
\hline
\end{tabular}


Variabel dependen memiliki delapan indikator diantaranya: hedonisme, flow, escapism, pembelajaran, sosialisasi, komuintas, kebaharuan/novelty, pujian da ri yang la in. Berdasarkan data dari tabel 2, diperoleh pula nila i standar deviasi variabel independen lebih da ri 0,6 ya itu diatas 0,7. Nilai standar deviasi setiap indikator dari variabel dependen lebih dari 0,7 yang memiliki makna indikator sudah homongen. Nilai mean pada indikator variabel dependen juga berada diatas 3 yang menunjukkan respon dari responden masih berada dalam kategorisasi Setuju.

\section{Analisis Structural Equation Modeling}

Data-data yang diperoleh dari jawaban kuesioner responden direkapitulasi dan dianalisis mengguna kan metode Structural Equation Modelling (SEM) dengan a plikasi IBM SPSS AMOS 22. Tahapan a nalisa pertama a dalah pengembangan model teoritis dan dia gram ja lur, serta memilih jenis input matriks dan estimasi model yang diusulkan. Berdasarkan teori dari penelitian terdahulu yang dilakukan oleh (Triantafillidou, Siomkos dan Papafilippaki, 2017) dan (Dey dan Srivastava, 2017), peneliti membentuk suatu model penelitian yang terdiri da $\dot{n}$ 4 variabel independen dan 1 variabel dependen; yang kemudian diuji validitasnya agar dapat lolos memenuhi kniteria pengujian selanjutnya pada Figure 2 kemudian diolah dengan menggunakan metode Maximum Likelihood; sehingga menghasilkan 2 jenis model yaitu model unstandardized dan model standardized.

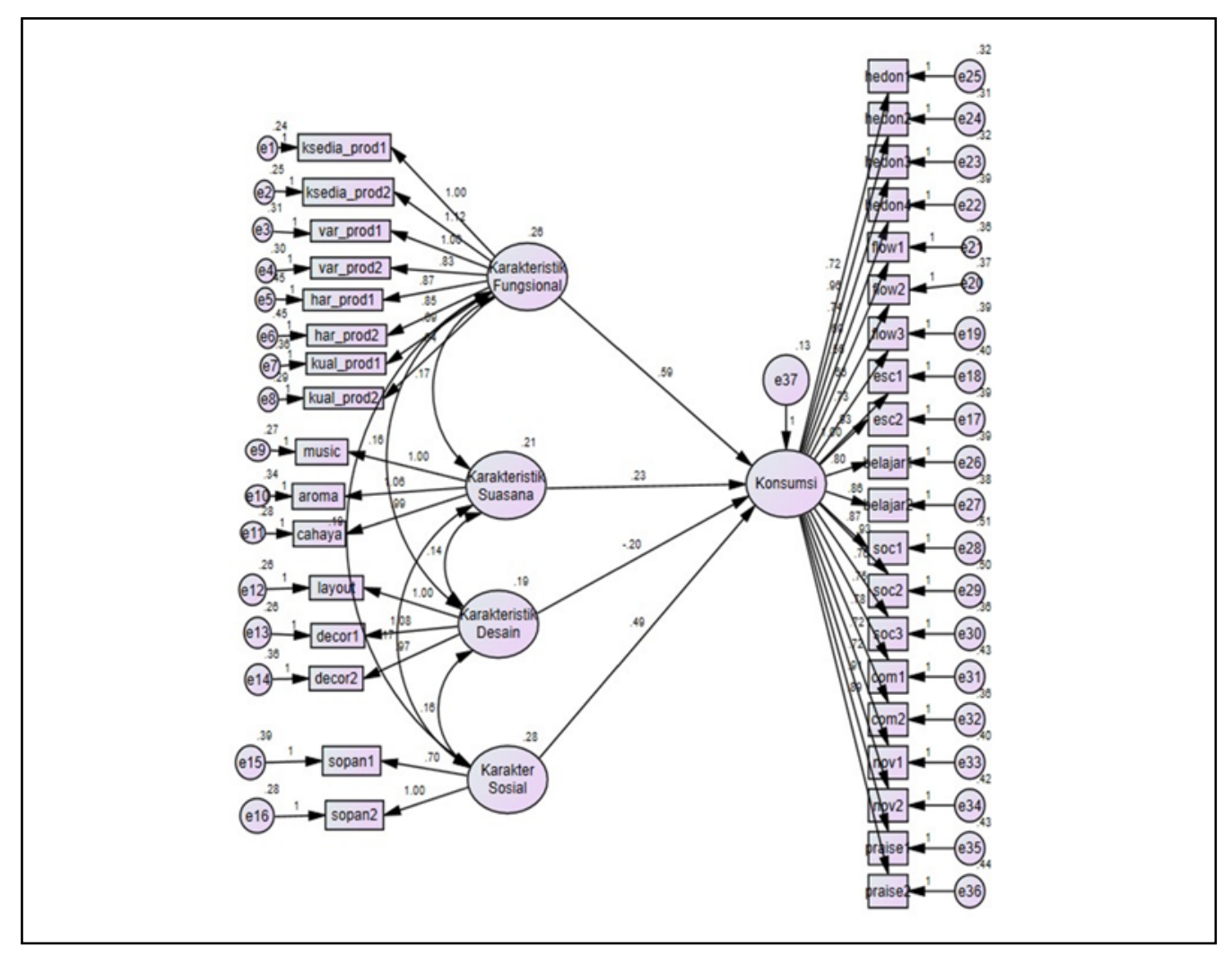

Gambar 2.

Model Penelitian Unstandardized 


\section{Sri Nathasya BR Sitepu \\ Angelica Irene Christina}

Tahapan sela njutnya a da lah uji noma litas data. Pa da Uji Nomalitas a wal diperoleh nila i c.r. multivariate sebesar 33.186, sehingga harus ada data outlier yang dibuang. Deteksi data outlier dilakukan dengan mengamati nilai Mahalanobis d-squared pada Output Mahalanobis Distance, di mana data yang jauh dari nilai centroid-nya dianggap outlier dan dibuang. Kniteria data outlier dapat dilihat berdasarkan nila i chi-squares dengan probabilitas 0,001 dan nilai degree of freedom 36, yang merupa kan jumlah pertanya an va riabel indikator da lam penelitian ini (Haryono, 2017). Nilai Ma ha la nobis d-squared penelitian ini berdasar nilai chi-square adalah 67,985 (36; 0,001). Pada Output Mahalanobis Distance awal, terdapat banyak data dengan nilai Mahalanobis d-squared yang jauh di atas 67,985. , maka dilakukan reduksi data outlier kali hingga nomalitasnya berada pada rentang yang baik dimana 72 kuesioner dibuang sehingga hanya 369 kuesioner yang digunakan. Uji nomalitas a khir menunjukkan nilai c.r. Multivariate sebesar 1.199, sehingga dapat disimpulkan bahwa distribusi data sudah nomal karena nilai 1,199 berada di dalam rentang -2,58 hingga 2,58. Sela in itu, nilai-nilai Mahala nobis d-squared sudah berada di bawah nilai 67,985, yang berarti sudah tidak ada data outlier.

Setelah diyakini tidak ada offending estimate dan data outlier, maka analisis dilanjutkan pada tahap uji multikolinearitas, yang bertujuan untuk melihat apakah ada pengaruh yang kuat antar variabel independen (eksogen). Dari output Sample Covariances dapat dilihat nila i output Deteminant of sample covariance matrix sebesar 0,000 . Karena nilainya sangat kecil, dapat disimpulkan terjadi multikolinearitas. Namun meski begitu berdasarkan nilai korelasi pada output Sample Correlations, tidak ada korelasi antar variabel yang nila inya di atas 0,90, sehingga dapat disimpulkan bahwa tidak ada multikolinearitas berdasarkan nila i korelasi a ntar varia bel. Maka data-data da lam penelitian dapat dila njutkan kembali.

Pada tahap evaluasi Godness-of-Fit, ha sil Notes for Group dan Notes for Modelmenunjukkan bahwa model penelitian ini adalah model recursive, yang artinya di dalam model penelitian tidak ada hubungan regresi resiprokal (timbal-balik) antar variabel la tennya; dengan jumlah sampel penelitian 369 data. Nilai degree of freedom (df) dapat dihitung dengan mengurangi jumlah data dengan jumlah parameter yang diestimasi; sehingga (666-82) = 584; sesuai dengan hasil output. Karena nilai df positif, maka model penelitian ini over identified, yang berarti model penelitian memiliki jumlah parameter estimasi lebih kecil daripada jumlah data yang diketahui; sehingga model penelitian dapat dilanjutkan. Nilai chi-square model adalah 1.442,467 dengan probabilitas 0,000; yang menunjukkan nilai chisquare $\left(\mathrm{X}^{2}\right)$ tinggi sehingga menghasilkan nilai probabilitas lebih kecil dari tingkat signifikansi $(p \leq 0,05)$. Peneliti menggunakan pengukuran model fit dengan data pada Tabel 4 . Nilai ECVI (Expected Cross-Validation Index), nilai AIC (Akaike Information Criterion), dan nilai CAIC (Consistent Akaike Information Criterion) memiliki kniteria good fit jika nila inya kecil dan 
lebih dekat dengan nilai saturated model-nya. Berdasarkan tampilan pada Tabel 4 dapat disimpulkan bahwa model penelitian telah memenuhi 4-5 kniteria Goodness-of-Fit sebagai penilaian kelayakan model tersebut, di mana masing-masing kriteria Absolute, Incremental, dan Parsimony Fit Indices terwakili (Haryono, 2017). Widarjono (2015:236) juga menyatakan bahwa sebagai rule of thumb, model dapat dianggap layak jika salah satu saja kriteria Goodness-Of-Fit terpenuhi. Maka dari itu, a na lisis da pat dila njutkan.

Tabel 4.

Ukuran Model Fit Penelitian

\begin{tabular}{|c|c|c|c|c|}
\hline $\begin{array}{c}\text { Ukuran } \\
\text { Goodness-of } \\
\text { Fit (GOF) }\end{array}$ & $\begin{array}{c}\text { Good Fit } \\
\text { Saturated } \\
\text { Model }\end{array}$ & $\begin{array}{c}\text { Marginal Fit } \\
\text { Independence } \\
\text { Model }\end{array}$ & $\begin{array}{l}\text { Nilai Model } \\
\text { Penelitian }\end{array}$ & Keterangan Uji \\
\hline \multicolumn{5}{|c|}{ Absolute Fit Measure } \\
\hline RMR & \multirow{2}{*}{\multicolumn{2}{|c|}{$\begin{array}{l}\leq 0.05 \\
\leq 0,08\end{array}$}} & 0,035 & Good Fit \\
\hline RMSEA & & & 0,063 & Good Fit \\
\hline GFI & $\geq 0,9$ & $0,8 \leq \mathrm{GFI}<0,9$ & 0,804 & Marginal Fit \\
\hline ECVI & 3.62 & 17.059 & 4.365 & Good Fit \\
\hline \multicolumn{5}{|c|}{ Incremental Fit Measure } \\
\hline $\mathrm{NFI}$ & $\geq 0,9$ & $0,8 \leq \mathrm{NFI}<0,9$ & 0,768 & Poor Fit \\
\hline ד / NNFI & $\geq 0,9$ & $0,08 \leq \mathrm{TLI}<0,9$ & 0,834 & Good Fit \\
\hline AGFI & $\geq 0,9$ & $0,8 \leq \mathrm{AGFI}<0,9$ & 0,777 & Poor Fit \\
\hline CFI & $\geq 0,9$ & $0,08 \leq \mathrm{CFI}<0,9$ & 0,846 & Marginal Fit \\
\hline IFI & $\geq 0,9$ & $0,08 \leq \mathrm{IFI}<0,9$ & 0,847 & Marginal Fit \\
\hline RFI & $\geq 0,9$ & $0,08 \leq \mathrm{RFI}<0,9$ & 0,749 & Poor Fit \\
\hline \multicolumn{5}{|c|}{ Parsimonius Fit Measure } \\
\hline CMIN / DF & $\begin{array}{c}1,0 \leq \mathrm{CMIN} / \\
\text { DF }<3,0\end{array}$ & $\begin{array}{c}3,0 \leq \mathrm{CMIN} / \mathrm{DF}< \\
5,0\end{array}$ & 2,470 & Good Fit \\
\hline $\begin{array}{l}\text { AIC } \\
\text { CAIC }\end{array}$ & $\begin{array}{c}1.332 \\
4602591\end{array}$ & $\begin{array}{l}6.277,767 \\
6454556\end{array}$ & $\begin{array}{l}1.606,467 \\
2009153\end{array}$ & Good Fit \\
\hline & & $0.4 \mathrm{~J} 4, \mathrm{~J} 00$ & & \\
\hline
\end{tabular}

Sela njutnya pada uji validitas, berdasarkan hasil output regression weight di Tabel 5 diketa hui bahwa keselunuhan indikator valid karena semuanya bemilai standard $\geq 0,5$, sehingga tidak ada indikator yang perlu dibuang dan kriteria Convergent Validity terpenuhi. Untuk menguatkan, seluruh indikator memiliki nilai $P \leq 0,05$, bahkan kurang dari 0,000 (ditandai dengan ${ }^{* * *}$ ) dan memiliki nilai C.R. $\geq 1,96$; sehingga dapat diketahui bahwa seluruh indikator penelitian signifikan. Hasil uji Convergent Validity dapat dilihat melalui nilai factor loading standardized regression weight dari tiap indikator, di mana bila nilai loading factor standard $\geq 0,5$ (Igbaria et al., dalam (Haryono, 2017) sehingga dapat disimpulkan bahwa uji convergent validity terpenuhi. Selain itu, dapat disimpulkan bahwa indikator $X_{1.1 .2}$ berpenga ruh tertinggi sebesar 0,754 terha dap va riabel Ka ra kteristik Fungsional; indika tor $\mathrm{Y}_{1.2}$ memiliki penga ruh tertinggi terha dap va riabel Penga la ma n Konsumsi sebesa $\mathrm{r}$,746; ind ikator $\mathrm{X}_{4.1 .2}$ memiliki pengaruh tertinggi terha dap varia bel Ka ra kteristik Sosial sebesar 0,704 ; va riabel $X_{3.2 .1}$ memiliki pengaruh tertinggi terhadap variabel Karakteristik Desa in sebesar 0,673; dan indikator $X_{2.1}$ berpengaruh paling tinggi terhadap variabel Karakteristik Suasana sebesar 0,659 . 
Tabel 5.

Ha sil Output Standa rd ized Regression Weights Anta r Ind ika tor Penelitia n

\begin{tabular}{|c|c|c|c|c|c|c|c|}
\hline & & & Estimate & S.E. & C.R. & $\mathbf{P}$ & Regression Weight \\
\hline $\mathrm{X} 1.1 .1$ & $<-$ & Karakteristik Fungsional & 1.000 & & & & 0,720 \\
\hline $\mathrm{X} 1.1 .2$ & $<-$ & Karakteristik_Fungsional & 1.121 & 0.083 & 13.467 & **1* & 0,754 \\
\hline $\mathrm{X} 1.2 .1$ & $<-$ & Karakteristik_Fungsional & 1.001 & 0.082 & 12.175 & $* 1 *$ & 0,679 \\
\hline $\mathrm{X} 1.2 .2$ & $<-$ & Karakteristik_Fungsional & 0.833 & 0.076 & 11.022 & $* 1 *$ & 0,614 \\
\hline $\mathrm{X} 1.3 .1$ & $<-$ & Karakteristik_Fungsional & 0.873 & 0.087 & 9.990 & $* 2 *$ & 0,556 \\
\hline $\mathrm{X} 1.3 .2$ & $<-$ & Karakteristik_Fungsional & 0.850 & 0.087 & 9.778 & $* 1 *$ & 0,544 \\
\hline $\mathrm{X} 1.4 .1$ & $<-$ & Karakteristik_Fungsional & 0.694 & 0.076 & 9.168 & *atk & 0,510 \\
\hline $\mathrm{X} 1.4 .2$ & $<-$ & Karakteristik_Fungsional & 0.645 & 0.069 & 9.359 & $* 1 *$ & 0,521 \\
\hline $\mathrm{X} 2.1$ & $<-$ & Ka rakteristik_Suasa na & 1.000 & & & & 0,659 \\
\hline$X 2.2$ & $<-$ & Karakteristik_Sua sana & 1.065 & 0.110 & 9.681 & $* 1 *$ & 0,644 \\
\hline$X 2.3$ & $<-$ & Ka rakteristik_Sua sa na & 0.993 & 0.101 & 9.800 & *atk & 0,656 \\
\hline X3.1 & $<-$ & Ka rakteristik_Desa in & 1.000 & & & & 0,645 \\
\hline X3.2.1 & $<-$ & Ka rakteristik_Desa in & 1.077 & 0.113 & 9.518 & *a*k & 0,673 \\
\hline X3.2.2 & $<-$ & Ka rakteristik_Desa in & 0.968 & 0.113 & 8.532 & **1* & 0,572 \\
\hline X4.1.1 & $<-$ & Karakter_Sosial & 0.699 & 0.091 & 7.665 & $* * *$ & 0,506 \\
\hline$X 4.1 .2$ & $<-$ & Karakter_Sosial & 1.000 & & & & 0,704 \\
\hline Y1.1 & $<-$ & Konsumsi & 0.724 & 0.061 & 11.950 & $* 1 *$ & 0,636 \\
\hline Y1.2 & $<-$ & Konsumsi & 0.959 & 0.068 & 14.086 & **** & 0,746 \\
\hline Y1.3 & $<-$ & Konsumsi & 0.743 & 0.061 & 12.217 & * * & 0,650 \\
\hline Y1.4 & $<-$ & Konsumsi & 0.691 & 0.063 & 10.967 & $* 1 *$ & 0,584 \\
\hline Y2.1 & $<-$ & Konsumsi & 0.558 & 0.058 & 9.647 & *atk & 0,515 \\
\hline Y2.2 & $<-$ & Konsumsi & 0.661 & 0.061 & 10.803 & $* 1 *$ & 0,576 \\
\hline Y2.3 & $<-$ & Konsumsi & 0.727 & 0.064 & 11.293 & $* * *$ & 0,601 \\
\hline Y3.1 & $<-$ & Konsumsi & 0.925 & 0.071 & 12.976 & $* 1 *$ & 0,689 \\
\hline Y3.2 & $<-$ & Konsumsi & 1.000 & & & & 0,720 \\
\hline Y4.1 & $<-$ & Konsumsi & 0.802 & 0.067 & 12.010 & $* 1 *$ & 0,639 \\
\hline Y4.2 & $<-$ & Konsumsi & 0.857 & 0.068 & 12.629 & **1* & 0,671 \\
\hline Y5.1 & $<-$ & Konsumsi & 0.865 & 0.075 & 11.558 & $* 1 *$ & 0,615 \\
\hline Y5.2 & $<-$ & Konsumsi & 0.933 & 0.076 & 12.239 & $* 1 *$ & 0,651 \\
\hline Y5.3 & $<-$ & Konsumsi & 0.759 & 0.064 & 11.907 & $* 1 * k$ & 0,633 \\
\hline Y6.1 & $<-$ & Konsumsi & 0.749 & 0.067 & 11.172 & $* * *$ & 0,595 \\
\hline Y6.2 & $<-$ & Konsumsi & 0.775 & 0.064 & 12.100 & $* \alpha *$ & 0,643 \\
\hline Y7.1 & $<-$ & Konsumsi & 0.718 & 0.065 & 11.066 & $* 1 *$ & 0,590 \\
\hline Y7.2 & $<-$ & Konsumsi & 0.725 & 0.066 & 11.001 & $* 2 *$ & 0,586 \\
\hline Y8.1 & $<-$ & Konsumsi & 0.910 & 0.072 & 12.555 & $* 1 *$ & 0,667 \\
\hline Y8.2 & $<-$ & Konsumsi & 0.889 & 0.072 & 12.362 & 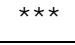 & 0,657 \\
\hline
\end{tabular}

Uji reliabilitas digunakan untuk mengetahui reliabilitas konstruk laten, yang menunjukkan seberapa reliabel indikator penelitian ini membentuk variabel penelitiannya. Penilaian reliabilitas dilakukan melalui 2 uji: uji Construct Reliability dan uji Variance Extracted. Nilai minimal cut-off Construct Reliability 0,70 dan nila i cut-off Variance Exc tracted 0,50 (Haryono, 2017). Nilai Standard Loading diperoleh dari nilai Loading Factor Standardized Regression Weight, dan nilai e sebagai mea surement emor tia $p$ indikator $=1$ - (Standard Loading) 2 . 
Tabel 6.

Hasil Perhitungan Uji Relia bilitas Konstruk

\begin{tabular}{|c|c|c|c|c|c|c|c|}
\hline Var & Ind & Sub-Ind & $\begin{array}{c}\text { Std. } \\
\text { Load }(\lambda)\end{array}$ & $\lambda^{2}$ & $\begin{array}{c}\text { Error }=1- \\
\lambda^{2}\end{array}$ & $\mathrm{CR}=\frac{\left(\sum \lambda\right)^{2}}{\left(\sum \lambda\right)^{2}+\sum e}$ & $\mathrm{AVE}=\frac{\left(\sum \lambda^{2}\right)}{\left(\sum \lambda^{2}+\sum e\right.}$ \\
\hline \multirow{9}{*}{$\mathrm{X} 1$} & \multirow{2}{*}{$X_{1.1}$} & $\mathrm{X}_{1.1 .1}$ & 0,720 & 0,5184 & 0,4816 & \multirow{9}{*}{$\begin{array}{c}0,7041 \\
\approx 0,7 \\
\text { (Reliabel) }\end{array}$} & \multirow{9}{*}{$\begin{array}{l}0,5435 \\
\approx 0,6 \\
\text { (Baik) }\end{array}$} \\
\hline & & $X_{1.1 .2}$ & 0,754 & 0,5685 & 0,4315 & & \\
\hline & \multirow{2}{*}{$X_{1.2}$} & $\mathrm{X}_{1.2 .1}$ & 0,679 & 0,4610 & 0,5390 & & \\
\hline & & $\mathrm{X}_{1.2 .2}$ & 0,614 & 0,3770 & 0,6230 & & \\
\hline & \multirow{2}{*}{$X_{1.3}$} & $X_{1.3 .1}$ & 0,556 & 0,3091 & 0,6909 & & \\
\hline & & $X_{1.3 .2}$ & 0,544 & 0,2959 & 0,7041 & & \\
\hline & \multirow{2}{*}{$X_{1.4}$} & $X_{1.4 .1}$ & 0,510 & 0,2601 & 0,7399 & & \\
\hline & & $\mathrm{X}_{1.4 .2}$ & 0,521 & 0,2714 & 0,7268 & & \\
\hline & $\sum$ & & 4,898 & 30,616 & 49,384 & & \\
\hline \multirow{4}{*}{$\mathrm{X} 2$} & & & 0,659 & 0,4343 & 0,5657 & \multirow{4}{*}{$\begin{array}{c}0,6904 \approx 0,7 \\
\quad(\text { Relia bel) }\end{array}$} & \multirow{4}{*}{$\begin{array}{c}0,4265 \approx 0,4 \\
\text { (Kurang } \\
\text { Baik) }\end{array}$} \\
\hline & & & 0,644 & 0,4147 & 0,5853 & & \\
\hline & & & 0,656 & 0,4303 & 0,5697 & & \\
\hline & & & 1,959 & 12,794 & 17,206 & & \\
\hline \multirow{4}{*}{ X3 } & & & 0,645 & 0,4160 & 0,5840 & \multirow{4}{*}{$\begin{array}{c}0,6645 \approx 0,6 \\
\text { (Relia bel) }\end{array}$} & \multirow{4}{*}{$\begin{array}{c}0,39875 \\
\approx 0,4 \\
\text { (Kurang } \\
\text { Baik) }\end{array}$} \\
\hline & Y2? & $X_{3.2 .1}$ & 0,673 & 0,4529 & 0,5471 & & \\
\hline & $\lambda 3.2$ & $X_{3.2 .2}$ & 0,572 & 0,3272 & 0,6728 & & \\
\hline & & & 1,890 & 11,961 & 18,039 & & \\
\hline \multirow{3}{*}{$X 4$} & $\times 41$ & $\mathrm{X}_{4.1 .1}$ & 0,506 & 0,2560 & 0,7440 & \multirow{3}{*}{$\begin{array}{c}0,5398 \approx 0,6 \\
\quad(\text { Relia ble })\end{array}$} & \multirow{3}{*}{$\begin{array}{c}0,37585 \\
\approx 0,4 \\
\text { (Kurang } \\
\text { Baik) }\end{array}$} \\
\hline & $\lambda 4.1$ & $X_{4.1 .2}$ & 0,704 & 0,4956 & 0,5044 & & \\
\hline & \multicolumn{2}{|c|}{$\Sigma$} & 1,210 & 0,7517 & 12,483 & & \\
\hline \multirow{21}{*}{ Y } & \multirow{5}{*}{$Y_{1}$} & $Y_{1.1}$ & 0,636 & 0,4045 & 0,5955 & \multirow{21}{*}{$\begin{array}{c}0,9308 \approx 0,9 \\
(\text { Relia ble })\end{array}$} & \multirow{21}{*}{$\begin{array}{c}0,40365 \\
\approx 0,4 \\
\text { (Kurang } \\
\text { Baik) }\end{array}$} \\
\hline & & $Y_{1.2}$ & 0,746 & 0,5565 & 0,4435 & & \\
\hline & & $Y_{1.3}$ & 0,650 & 0,4225 & 0,5775 & & \\
\hline & & $Y_{1.4}$ & 0,584 & 0,3411 & 0,6589 & & \\
\hline & & $Y_{2.1}$ & 0,515 & 0,2652 & 0,7348 & & \\
\hline & \multirow[t]{2}{*}{$Y_{2}$} & $Y_{2.2}$ & 0,576 & 0,3318 & 0,6682 & & \\
\hline & & $Y_{2.3}$ & 0,601 & 0,3612 & 0,6388 & & \\
\hline & \multirow{2}{*}{$Y_{3}$} & $Y_{3.1}$ & 0,689 & 0,4747 & 0,5253 & & \\
\hline & & $Y_{3.2}$ & 0,720 & 0,5184 & 0,4816 & & \\
\hline & \multirow{3}{*}{$Y_{4}$} & $Y_{4.1}$ & 0,639 & 0,4083 & 0,5917 & & \\
\hline & & $Y_{4.2}$ & 0,671 & 0,4502 & 0,5498 & & \\
\hline & & $Y_{5.1}$ & 0,615 & 0,3782 & 0,6218 & & \\
\hline & $Y_{5}$ & $Y_{5.2}$ & 0,651 & 0,4238 & 0,5762 & & \\
\hline & & $Y_{5.3}$ & 0,633 & 0,4007 & 0,5993 & & \\
\hline & & $Y_{6.1}$ & 0,595 & 0,3540 & 0,6460 & & \\
\hline & $Y_{6}$ & $Y_{6.2}$ & 0,643 & 0,4134 & 0,5866 & & \\
\hline & $Y_{7}$ & $Y_{7.1}$ & 0,590 & 0,3481 & 0,6519 & & \\
\hline & $Y_{7}$ & $Y_{7.2}$ & 0,586 & 0,3434 & 0,6566 & & \\
\hline & $Y_{0}$ & $Y_{8.1}$ & 0,667 & 0,4449 & 0,5551 & & \\
\hline & $Y_{8}$ & $Y_{8.2}$ & 0,657 & 0,4316 & 0,5684 & & \\
\hline & & i & 12,664 & 80,727 & 119,273 & & \\
\hline
\end{tabular}

Berdasarkan Tabel 6, bahwa variabel Y (Pengalaman Konsumsi) memiliki nilai Construct Reability yang sangat tinggi $(0,9308)$, diikuti dengan variabel $X_{1}$ sebesar 0,7041 . Nilai $X_{2}$ $(0,6904)$ dan $X_{3}(0,6645)$ sedikit di bawah nilai cut-off Construct Reliability, namun masih dapat dibulatkan menjadi 0,7 . Nilai $X_{4}(0,5398)$ yang berada di bawah nilai cut-off Construct 


\section{Sri Nathasya BR Sitepu \\ Angelica Irene Christina}

Reliability. Meski begitu, nilai Construct Reliability di bawah 0,6-0,7 masih dapat diterima dengan syarat validitas indikator dalam model baik (Ghozali, 2017b). Menujuk pada hasil uji validita s sebelumnya, kedua ind ika tor $\mathrm{X}_{4}$ memiliki va lid itas yang sangat baik, sehingga angka Construct Reliability ini diterima. Maka dapat disimpulkan semua variabel dan indikator penelitian ini reliabel dan penelitian ini dapat dilanjutkan.

Dari Table 6 juga diketahui nila i Variance Extracted pada variabel $X_{1}(0,5435), X_{2}(0,4265), X_{3}$ $(0,3987), X_{4}(0,3758)$, dan $Y(0,4036)$. Semakin tinggi nilai VE variabel menunjukkan bahwa indikator-indikatomya mewakili variabel laten tersebut dengan baik. Nilai VE yang di atas nilai cut-off $(0,5)$ hanya pada variabel $X_{1}$, sementara nilai VE variabel $X_{2}, X_{3}, X_{4}$, dan $Y$ di bawah nilai cut-off, sehingga dapat disimpulkan bahwa hanya indikator pada variabel $X_{1}$ yang mampu mewakili variabel latennya dengan baik, sedangkan indikator-indikator pada variabel $X_{2}, X_{3}, X_{4}$, dan $Y$ kurang menunjukkan kemampuannya mewakili variabel latennya dengan baik.

Besamya nilai koefisien determinasi ditunjukkan oleh nilai Squared Multiple Correlation $\left(\mathrm{R}^{2}\right)$ yang menunjukkan seberapa besar kontribusi variabel eksogen terhadap variabel endogennya. Variabel endogen pada penelitian ini (Pengalaman Konsumsi) dapat dijelaskan oleh variabel Karakteristik Fungsional $\left(X_{1}\right)$, Karakteristik Suasana $\left(X_{2}\right)$, Karakteristik Desa in $\left(X_{3}\right)$, dan Karakteristik Sosial $\left(X_{4}\right)$ sebesar $68,7 \%$; sedangkan $31,3 \%$ sisanya dijela skan oleh variabel lainnya yang tidak saya teliti. Hal ini menunjukkan bahwa model struktural penelitian ini rendah, namun masih bisa dilanjutkan.

Setelah melalui berbagai uji kelayakan, maka penelitian dapat dilanjutkan ke tahap pengujian hipotesis, dengan menggunakan nilai t-value pada signifikansi 0,05. Nilai t-value ini dapat dilihat dari nilai Critic al Ratio (C.R.) dan probabilitasnya; di mana bila nilai C.R. $\geq 1,96$ atau nilai $\mathrm{P} \leq 0,05$, bahkan kurang dari 0,000 (ditandai dengan ${ }^{* * *}$ ), maka hipotesis diterima.

Tabel 7.

Hasil Output Standa rdized Regression Weights Varia bel Laten

\begin{tabular}{lcccccc}
\hline & Estimate & S.E. & C.R & P & $\begin{array}{c}\text { Regression } \\
\text { Weight }\end{array}$ & Hipotesis \\
\hline $\begin{array}{l}\text { Konsumsi } \leftarrow \text { Karakteristik } \\
\text { Fungsional }\end{array}$ & 0.591 & 0.128 & 4.615 & *** & 0,468 & Diterima \\
\hline $\begin{array}{l}\text { Konsumsi } \leftarrow \text { Karakteristik } \\
\text { Sua sana }\end{array}$ & 0.232 & 0.153 & 1.521 & 0.128 & 0,165 & Ditolak \\
\hline $\begin{array}{l}\text { Konsumsi } \leftarrow \text { Karakteristik Sosial } \\
\text { Konsumsi } \leftarrow \text { Karakteristik }\end{array}$ & 0.485 & 0.185 & 2.623 & 0.009 & 0,395 & Ditolak \\
\hline Desa in & -0.201 & 0.177 & -1.134 & 0.257 & $-0,135$ & Diterima \\
\hline
\end{tabular}


Tabel 7 menunjukkan bahwa pengaruh karakteristik fungsional terhadap variabel konsumsi memiliki nilai C.R. $(4.615) \geq 1,96$ atau nilai $P\left(0,000\left({ }^{* * *}\right)\right) \leq 0,05$; sehing ${ } \mathrm{H}_{1}$ diterima, yang dapat diartikan bahwa karakteristik fungsional gerai Starbucks di Surabaya benengaruh signifikan terhadap aspek pengalaman yang diperoleh konsumen Starbucks. Variabel ka rakteristik fungsional dengan indikator ketersediaan, harga, dan kualitas produk terbukti sangat mempengaruhi pengalaman konsumsi yang diperoleh konsumen, sesuai dengan hasil penelitian (Triantafillidou, Siomkos dan Papafilippaki, 2017). Hasil penelitian ini juga menemukan bahwa indikator variasi produk juga mendukung pengaruh karakteristik fungsional Starbucks terhadap pengalaman konsumsi konsumen, walaupun penelitian (Triantafillidou, Siomkos dan Papafilippaki, 2017) menemukan bahwa variasi produk berpengaruh negatif terhadap variabel pembelajaran konsumen.

Seperti halnya di luar negeri, Starbucks menjadi salah satu tempat populer untuk hangout santai maupun meeting bagi para pelajar, pekerja ataupun businessman yang ada di kotakota besar di Indonesia, tidak terkecuali di Surabaya. Penelitian ini mendukung fakta bahwa salah satu penyebab konsumen Indonesia memilih Starbucks dibandingkan gerai kopi lainnya adalah konsumen puas dengan berbagai karakteristik fungsional yang ditawarkan Starbucks. Mulai dari ketersediaan produk di Starbucks Surabaya yang selalu lengkap dan juga bervariasi, baik produk makanan-minuman maupun produk merchandise (non-food) Starbucks. Starbucks Surabaya bahkan juga menyediakan berbagai menu makananminuman juga merchandise seasonal, seperti Praline Mocha menjelang dan selama har Natal, atau minuman Chemy Mocha dan Red Velvet Loaf Cake selama bulan Valentine. Starbucks Surabaya juga mengikuti budaya dari Starbuck la innya yang ada di luar negeri, dengan menyediakan menu-menu minuman rahasia (secret recipe) yang dapat dipesan dengan memintanya langsung kepada barista. Hal inilah yang mendorong konsumen merasa senang, bahkan cenderung bangga saat bisa memamerkan produk-produk unik Starbucks kepada teman-temannya.

Starbucks terkenal dengan harga-harga produknya yang cukup tinggi, namun sebanding dengan kualitasnya yang tinggi. Hal ini disetujui oleh beberapa responden penelitian ini. Kualitas produk di Starbucks Surabaya sudah terstandardisasi, sehingga kapan saja konsumen membeli produk Starbucks di Surabaya mereka akan memperoleh produk yang sama-sama berkualitas tinggi. Konsumen Starbucks Surabaya juga setuju bahwa harga produk Starbucks kurang terjangkau, dan jauh lebih tinggi dibandingkan dengan kedai kopi la innya. 


\section{Sri Nathasya BR Sitepu \\ Angelica Irene Christina}

Tabel 7 juga menunjukkan bahwa pengaruh karakteristik suasana terhadap pengalaman konsumsi konsumen Starbucks Surabaya memiliki nilai C.R. $(1.512) \leq 1,96$ atau nilai $P(0,128) \geq$ 0,05; sehing ga $\mathrm{H}_{2}$ ditolak, yang mengind ika sikan bahwa ka rakteristik sua sa na gerai Starbucks di Surabaya tidak berpengaruh terhadap aspek pengalaman yang diperoleh konsumen Starbucks. Hasil penelitian pada aspek suasana toko sesuai dengan penelitian Pragita, DH dan Kumadji (2013) yang memperoleh hasil bahwa suasana toko terutama ruangan redup tidak dapat memberikan rasa nyaman kepada konsumen yang mengunjungi toko. Musik yang diputar di Starbucks biasanya memiliki genre easy listening yang cukup jelas (Wicaksono dan Prihastuti, 2017). Musik di Starbucks Surabaya biasanya juga mengikuti momen-momen hari raya khusus yang sedang/akan berlangsung, seperti musik bertemakan Natal yang diputar sepanjang bulan Desember. Penelitian ini menemukan bahwa indikator musik tidak berpengaruh signifikan terhadap pengunjung Starbucks di Surabaya, yang didukung oleh hasil penelitian Hussain \& Ali (2015) dan Hongari (2017).

Aroma kopi yang tercium di gerai Starbucks Suraba ya tidak memberikan penga ruh signifikan terhadap pengalaman konsumsi konsumennya. Gerai Starbucks di Surabaya ini selain memiliki aroma kopi dan pencahayaan yang cukup terang, juga memiliki intensitas cahaya matahari dan udara yang cukup tinggi.Sistem pencahayaan yang berlebihan membuat konsumen kurang nyaaman (gerai terlalu terang). Hal ini mengakibatkan konsumen tidak betah menikmati suasana gerai walaupun dilengkapi dengan pencahayaan dan aroma kopi. Konsumen menjadi kesulitan mendapatkan pengalaman dari karakteristik suasana gerai kopi Starbuck. Kondisi pencahayaan ini sejalan dengan penelitian terdahulu pada gerai Starbuck di Surabaya Town Square yang menyarankan Starbucks Surabaya Town Square untuk mengganti wama cahaya lampu yang lebih contrast sehingga dapat menimbulkan kesan hangat dan mengundang (Dian \& Artanti, 2013). Kondisi aroma dan penca hayaan di Starbuc ks Sura baya ini tidak berpenga ruh signifikan terhadap pengala man konsumsi yang diperoleh konsumen, yang didukung oleh Triantafillidou, Siomkos dan Papa filippaki (2017).

Berdasarkan Tabel 7, tampak bahwa pengaruh karakteristik desain terhadap pengalaman konsumsi Starbucks Surabaya memiliki nilai C.R. $(-1.134) \leq 1,96$ atau nilai $P(0,257) \geq 0,05$; sehingga $\mathrm{H}_{3}$ ditolak, yang dapat disimpulkan bahwa karakteristik desain gerai Starbucks di Surabaya tidak berpengaruh signifikan terhadap aspek pengalaman yang diperoleh konsumen Starbucks. Hasil penelitian ini sesuai dengan penelitian Santoso (2016) dimana layout (desain interior) dalam atmosfer rumah makan belum cukup mampu mempengaruhi konsumen mengambil keputusan. Layout Starbucks Surabaya didesain dengan konsep minimalis dan terkesan homey, terlebih karena Starbucks didirikan sebagai kafe yang sekaligus menjadi tempat hangout dan berkumpul bersama bagi konsumennya. Hasil 
penelitian ini justru menemukan bahwa layout Starbucks Surabaya tidak berpengaruh signifikan, bahkan negatif terhadap pengalaman konsumsi yang diperoleh konsumen. Hal ini dapat mengindikasikan kondisi saat di dalam gerai Starbucks Surabaya terdapat banyak orang yang menyebabkan keadaan di dalam toko penuh sesak, sehingga konsumen merasa tidak nyaman berlama-lama di dalamnya dan akan memilih gerai lain. Kondisi peningkatan drastis jumlah pengunjung gerai Starbucks di Surabaya ini juga dipengaruhi oleh promo yang saat itu ditawarkan Starbucks, yang didukung oleh Coskun et al. (2019).

Starbucks Surabaya sendir memiliki dekorasi yang unik dan berdaya seni, serta memiliki beragam produk makanan dan merchandise yang dipajang dalam satu display tersendin dengan rapi. Penelitian ini menemukan bahwa dekorasi Starbucks tidak berdampak signifikan dan memberikan efek negatif terhadap pengalaman konsumsi di Starbucks Surabaya. Ketika konsumen berbelanja, mereka akan mengalami perasaan kebingungan berlebihan (overload confusion) saat dihadapkan dengan lingkungan toko yang penuh sesak, terutama jika ada terlalu banyak produk serupa yang dipajang di dalam satu rak yang sama. Dengan demikian, dapat diindikasikan bahwa display produk makanan dan merchandise di Starbucks Surabaya yang terla lu banyak di dalam satu display menimbulkan kebingungan konsumen, sehingga konsumen merasa kurang nyaman dan akhimya tidak jadi membeli produk.

Berdasarkan Tabel 7, menunjukkan bahwa pengaruh karakteristik sosial terhadap pengalaman konsumsi Starbucks Surabaya memiliki nilai C.R. $(2.623) \geq 1,96$ atau nilai $P(0,009)$ $\leq 0,05$; sehingga $\mathrm{H}_{4}$ diterima, yang meng ind ika sikan bahwa ka rakteristik sosial gerai Starbucks di Surabaya berpengaruh signifikan terhadap aspek pengalaman yang diperoleh konsumen Starbucks. Hal ini menunjukkan bahwa seluruh karyawan di Starbucks Surabaya bersikap sopan dan ramah terhadap semua pengunjung gerai, bahkan melakukan strategi penyebutan dan penulisan nama konsumen di gelasnya agar konsumen merasa akrab dan familier dengan karyawan Starbucks. Hal ini adalah penerapan aspek emosional yang sangat penting untuk menjaga hubungan dengan konsumen seka ligus sebaga i sala h inovasi dalam menjalankan bisnis (Keiningham et al., 2020). Keakraban dan rasa familier yang dirasakan konsumen inilah yang mendorong mereka untuk betah berlama-lama di dalam Starbucks Surabaya, meskipun hanya berdiam diri. Hasil penelitian ini juga mendukung penelitian sebelumnya yang menyatakan bahwa penampilan dan perilaku karyawan serta konsumen lain yang berada di gerai tersebut memiliki pengaruh positif dan signifikan terhadap perasaan gairah dan keinginan konsumen untuk membeli produk. 


\section{Sri Nathasya BR Sitepu \\ Angelica Irene Christina}

\section{KESIMPULAN}

Karaktenstik gerai kopi Starbucks Surabaya yang diamati dalam penelitian ini meliputi: karakteristik fungsional (keterjangkauan, varian, harga, dan kualitas produk), ka rakteristik suasana (musik background, aroma, dan pencahayaan), karakteristik desain (layout dan dekorasi), dan karakteristik sosial (kesopanan karyawan). Penelitian ini menemukan bahwa hanya karakteristik fungsional dan sosial yang berpengaruh signifikan bagi pengalaman konsumsi yang diperoleh konsumen saat berkunjung dan/atau mengonsumsi produk secara langsung di Starbucks Surabaya. Sedangkan karakteristik suasana dan desain tidak berpengaruh signifikan, bahkan karakteristik desain berpengaruh negatif terhadap pengalaman konsumsi konsumen Starbucks Sura baya.

Implikasi praktis penelitian ini bagi pelaku bisnis gerai kopi adalah pentingnya mempertahankan ketersediaan jumlah produk makanan-minuman serta merchandise (nonfood) untuk dijual kepada konsumen dan keanekaragaman varian produk baik yang tetap (selalu ada), seasonal, ma upun secret recipe. Gerai kopi juga perlu mengatur volume suara speaker di dekat kasir lebih tinggi, sehingga pembeli yang sedang bertransaksi juga dapat ikut menikmati musiknya. Meningkatkan kadar aroma kopi pada pengharum ruangan dan mengganti wama lampu (lebih soft) agar sesuai dengan dekorasi gerai juga akan menimbulkan kesan nyaman. Tidak kalah penting, mempertahankan sikap ramah, sopan, menyebutan dan menulis nama konsumen di gelasnya juga perlu konsisten dilakukan oleh karyawan.

Sela in implikasi praktis bagi pelaku bisnis gerai kopi, implikasi teoritis penelitian experiential marketing pada gerai kopi ini dapat menjadi tambahaan tinjauan literature penelitian manajemen pemeasaran. Tidak terlepas dari keterbatasan, penelitian ini hanya meneliti experiential marketing konsumen gerai starbuck khusus di Kota Surabaaya sehingga hasil penelitian mungkin belum belum tetu sama jika diterapkan bagi semua gerai kopidi Indonesia. Oleh karena itu, disarankan bagi penelitian selanjutnya untuk melakukan penelitian pada setiap gerai kopi yang ada di setiap kota di Indonesia sehingga, dapat melihat experiential marketing dari seluruh konsumen yang ada di Indonesia.

\section{DAFTAR PUSTAKA}

Ba dan Pusat Statistik. 2020. Istilah - Ba dan Pusat Statistik, Badan Pusat Sta tistik Web Site.

Badan Pusat Statistik Kota Surabaya. 2018. Kota Surabaya Dalam Angka - Surabaya Munic ipa lity in Figures 2018. Surabaya.

Bungin, B. 2015. Metodologi Penelitian Sosial \& Ekonomi: Format-format Kuantitatif dan Kualitatif untuk Studi Sosiologi, Kebijakan Publik, Komunikasi, Manajemen, dan Pemasaran, Edisi Pertama Cetakan ke-2. Jakarta: Prenadamedia Group. 
Coskun, M., Gupta, S. dan Bumaz, S. 2019. Human crowding and store messiness: Drivers of retail shopper confusion and behavioral intentions. J oumal of Consumer Behaviour 18: 313-331.

Datta, V. 2017. A Conceptual Study on Experiential Marketing: Importance, Strategic Issues and Its Impact. Intemational J oumal of Research-Grantha alayah 5(7): 26-30.

Dey, D. K. dan Srivastava, A. 2017. Impulse buying intentions of young consumers from a hedonic shopping perspective. Joumal of Indian Business Research.

Dian, N. F. dan Artanti, Y. 2013. Penga ruh Kelompok Acuan Dan Atmosfir Restoran Terhadap Keputusan Pembelian Konsumen Starbucks Coffee. Jumal Ilmu Manajemen 1(2): 414427.

Ghozali. 2017. Model Persamaan Struktural. Konsep dan Aplikasi Dengan Program AMOS 24.0. Update Bayesian SEM. Universitas Diponegoro.

Haryono, S. 2017. Metode SEM Untuk Penelitian Manajemen dengan AMOS USREL PLS. J akarta: Luxima Metro Media.

Hongari, E. A. 2017. Studi Deskriptif Customer Experience Berdasarkan Kano's Model di Starbucks Galaxy Mall Surabaya. Calyptra: Jumal Ilmiah Mahasiswa Universitas Surabaya 6(2): 761-774.

Hoyer, W. D. et al. 2020. Transforming the Customer Experience Through New Technologies. J oumal of Interactive Ma rketing.

Hussain, R. dan Ali, M. 2015. Effect of Store Atmosphere on Consumer Purchase Intention. Intemational J oumal of Marketing Studies 7(2): 35-43.

Johnson, K. K. P. et al. 2015. Keeping customers shopping in stores: interrelationships among store attributes, shopping enjoyment, and place attachment. The Intemational Review of Retail, Distribution and Consumer Research. Taylor \& Francis 25(1): 20-34.

Keining ham, T. et al. 2020. Customer Experience Driven Business Model Innovation. J oumal of Business Research 116: 431-440.

Leha, J. M. dan Subagio, H. 2014. Pengaruh Atribut Cafe Terhadap Motif Belanja Hedonik Motif Belanja Utulitarian Dan Loyalitas Pelanggan Starbucks Coffee di The Square Apartement Surabaya. J umal Manajemen Pemasaran Petra 2(1): 1-12.

Lucia-Palacios, L, Pérez-López, R. dan Polo-Redondo, Y. 2016. Cognitive, affective and behavioural responses in mall experience. Intemational J oumal of Retail \& Distribution Management.

Marlius, D. 2017. Keputusan Pembelian Berdasarkan Faktor Psikologis Dan Bauran Pemasaran Pada PT. Intercom Mobilindo Padang. J umal Pundi 1(1).

Melkisedek, M. H. 2017. Kafe sebagai Gaya Hidup Masyarakat Konsumerisme (Studi Kasus pada Starbucks). J umal Desa in Komunika si Visual Nimana 17(1): 53-58.

Merdin-Uygur, E. 2018. Chapter 5: Experience Consumption in Turkey. Marketing Management in Turkey : 223-244. 
Numanisa, A., Wilopo dan Sanawin, B. 2016. Analisis Customer Segment, Channels, dan Customer Relationship dalam pembentukan Value Proposition di Starbucks Coffee (Studi Ka sus pa da Sta rbucks Coffee Ind onesia ). J umal Ad ministra si Bisnis 34(1): 10-18.

Pine, B. J . I. dan Gilmore, J. H. 1999. The experience economy: work is theatre \&amp; every business a stage. Choice Reviews Online. Boston: Harvard Business Review Press 37(04): 37-2254-37-2254.

Pragita, A. A., DH, A. F. dan Kumadji, S. 2013. Pengaruh Store Atmosphere (Sua sana Toko) Terhadap Emosi Dan Dampaknya Kepada Keputusan Pembelian (Survei pada Pengunjung Baker's Kings di Mall Olimpic Garden Malang). Profit: Jumal Administrasi Bisnis 7(1).

Roggeveen, A. L., Grewal, D. dan Schweiger, E. B. 2020. The DAST framework for retail atmospherics: The impact of in-and out-of-store retail joumey touchpoints on the customer experience. J oumal of Retailing 96(1): 128-137.

Ryu, K. dan Jang, S. 2008. Influence of restaurant's physical environments on emotion and behavioral intention. The Service Ind ustries J oumal 28(8): 1151-1165.

Sachdeva, I. dan Goel, S. 2015. Retail store environment and customer experience: a paradigm. J oumal of Fa shion Marketing and Management.

Santoso, I. 2016. Peran kualitas produk dan layanan, harga dan atmosfer rumah makan cepat saji terhadap keputusan pembelian dan kepuasan konsumen. The Asian Joumal of Technology Management. Institut Teknologi Bandung, School of Business and Management, 15(1): 94.

Sitinjak, M. F., Pangaribuan, C. H. dan Tafriza, N. 2019. Do Store Atmosphere and Perceived Value Matter in Satiffying and Predicting the Millennia Is' Behavioral Intention in a Café Setting?. Binus Business Review10(1): 31-40.

Sukma, E. A., DH, A. F. dan Yaningwati, F. 2012. Sua sana toko dalam menciptakan emosi dan pengaruhnya terhadap keputusan pembelian (survey pada pengunjung retail Hypermart Malang Town Square Kota Malang). Profit : J uma Administra si Bisnis 6(1).

Sunyoto, D. 2013. Metode dan Instrumen Penelitian (Untuk Ekonomi dan Bisnis). Yogyakarta: CAPS (Center for Academic Publishing Service).

Triantafillidou, A. dan Siomkos, G. 2014. Consumption experience outcomes: satisfaction, nostalgia intensity, word-of-mouth communic ation and behavioural intentions. Joumal of Consumer Marketing.

Triantafillidou, A., Siomkos, G. dan Papafilippaki, E. 2017. The effects of retail store characteristics on in-store leisure shopping experience. Intemational Joumal of Retail and Distribution Management.

Uusitalo, O. 2001. Consumer perceptions of grocery retail formats and brands," Intemational J oumal of Retail \& Distribution Mana gement 29(5): 214-225.

Wicaksono, A. F. W. dan Prihastuti, D. R. 2017. Pengaruh Experiential Marketing terhadap 
Kepuasan pelanggan Starbucks Coffee Shop. Jumal Ekonomi Manajemen 2(1): 285302.

Widarjono, A. 2010. Ana lisis Sta tistika Multivariat Terapan, dilengka pi Aplika si SPSS dan AMOS. Yogyakarta: UPP STIM YKPN.

Widjoyo, I. O. 2013. Analisa pengaruh kualitas layanan terhadap kepuasan konsumen pada layanan drive thru McDonald's Basuki Rahmat di Surabaya. Jumal Strategi Pemasaran $1(1)$. 